\title{
The Application of Scanning Electron Microscopy with Energy Dispersive X-ray Spectroscopy (SEM-EDX) in Ancient Dental Calculus for the Reconstruction of Human Habits
}

\author{
Dana Fialova ${ }^{1}$, Radim Skoupy ${ }^{2}$, Eva Drozdova ${ }^{1}$, Vladislav Krzyzanek ${ }^{2}$, Lukas Sin $^{3}$, Radoslav Benus ${ }^{4}$, \\ Bohuslav Klima ${ }^{5}$ \\ 1. Department of Experimental Biology, Masaryk University, Brno, Czech Republic \\ 2. Institute of Scientific Instruments, The Czech Academy of Sciences, Brno, Czech Republic \\ 3. Archaeological Centre Olomouc, Czech Republic \\ 4. Department of Anthropology, Comenius University, Bratislava, Slovak Republic \\ ${ }^{5 .}$ Department of History, Faculty of Education, Masaryk University, Brno, Czech Republic
}

Ancient human dental calculus is a very important bio-archaeological material because it is formed from a dental plaque during the life of an individual. Various plant and animal micro remains, bacteria and elements can be trapped. Scanning electron microscopy (SEM) was used in many studies about human diet, oral bacterial flora, environmental conditions and habits of our ancestors which are also the main focus in this study. Energy dispersive X-ray spectroscopy (EDX) was used in studies of microfossils and starch in ancient dental calculus [1] [2]. Study by Charlier et al. 2010 [3] confirmed different individual elemental composition of dental calculus in 5 samples from the Etruscan-Celtic necropolis. Therefore, in this study EDX was used to verify theories about life and burial habits of chosen individuals. This selection makes the study unique.

This work describes the potential of scanning electron microscopy with energy dispersive X-ray spectroscopy (SEM-EDX) in detection of unusual chemical elements included in ancient human dental calculus in connection with life and burial habits of individual. It was applied on three archaeological samples of calculus from chosen individuals which came from $9^{\text {th }}$ century A.D. from early Mediaeval Period - the Great Moravian Empire from the Czech and Slovak Republic and from the $19^{\text {th }}$ century (from Napoleonic Wars) from the Czech Republic.

Samples of supragingival calculus (above the gum line), were taken manually in a flow box by germfree periodontal instruments (scaler, chisel) into sterile plastic bags. In order to avoid soil contamination only the side which adhered to the tooth was observed. The SEM-EDX analysis was conducted by the SEM Magellan 400 (FEI) equipped with the ED APOLLO X Silicon Drift Detector (EDAX) at $30 \mathrm{kV}$ accelerating voltage. The calculus samples were mounted on stubs using double-sided carbon tape. To prevent surface charging by the electron beam one sample was sputter coated with chromium. The results with an error smaller than $10 \%$ were placed more importance.

First sample came from the individual 464 from early Mediaeval Period ( $9^{\text {th }}$ century A.D.) from burial site Znojmo-Hradiste in the Czech Republic. Sex and age were estimated by anthropological methods. Individual was 53-58 years old man with high degree of dental abrasion (5-6 on a scale to 8), which was probably caused by grinding stones. This theory was verified by comparison of the elemental composition between dental calculus and grinding stones (found in Znojmo-Hradiste). In dental calculus there are unusual elements like magnesium, aluminum and silicate (Figure 1a) which are also the main elements of grinding stones from this population [4]. These results contribute to confirm the theory about high degree of dental abrasion caused by grinding stones.

Second sample came from a man 801 from site Majetin in the Czech Republic. Incisors of his lower jaw showed traces of the trauma of a military origin. Municipal chronicle of Majetin describes this area as a burial place of Napoleonic soldiers. More sensitive dating material (such as parts of military equipment) wasn't discovered. The SEM-EDX analysis was done to confirm the theory that damage of the teeth were caused by the systematic utilization of the teeth by opening paper cartridges (charge with the dose of gunpowder and bullet), that were used 
during the $18^{\text {th }}$ and $19^{\text {th }}$ century [5]. Figure $1 \mathrm{~b}$ shows elements unusual in dental calculus like iron, lead and copper in this sample, which contribute to confirmation of this theory.

Third sample came from the individual 53 from early Mediaeval Period $\left(9^{\text {th }}\right.$ century A.D.) from burial site Devin in Slovak Republic. Sex and age were estimated by anthropological methods. Individual was 30-39 years old man with no goods in a grave according archaeological records. Nevertheless, green coloring was noticed of 3 right upper teeth, so dental calculus was sampled from upper first molar. Green coloring suggest that some bronze jewelry could lie near buried body. Elemental spectrum (Figure 1c) shows high presence of copper (the primarily element of bronze) and magnesium and aluminum which could be the addition in this alloy. These results specify burial habits of this man.

All these results demonstrate the great potential of SEM-EDX in the study of life (first and second individual) and burial (third individual) habits of our ancestors through ancient human dental calculus analysis [6].

\section{References:}

[1] JV Dudgeon and M Tromp, International Journal of Osteoarchaeology 24 (2014), p. 634-648.

[2] RC Power et al, Journal of Archaeological Science 49 (2014), p. 160-169.

[3] Charlier et al, Legal Medicine 12 (2010), p. 163-171.

[4] S Šichnárková, Unpublished Master's thesis (Masaryk University, Brno) (2014).

[5] L Šín and J Vrána, Český lid 101:2 (2014) p. 149-169.

[6] The authors thank MEYS CR (LO1212), its infrastructure by MEYS CR and EC (CZ.1.05/2.1.00/01.0017).

a)

\begin{tabular}{|l|l|l|l|}
\hline Element & Weight & Atomic & Error \% \\
\hline $\mathrm{C}$ & 9.43 & 15.17 & 10.4 \\
\hline $\mathrm{O}$ & 49.24 & 59.48 & 9.26 \\
\hline $\mathrm{F}$ & 3.3 & 3.35 & 11.32 \\
\hline $\mathrm{Na}$ & 1.98 & 1.66 & 9.17 \\
\hline $\mathbf{M g}$ & $\mathbf{1 . 4 9}$ & $\mathbf{1 . 1 8}$ & $\mathbf{7 . 3 3}$ \\
\hline $\mathrm{Al}$ & $\mathbf{1 . 8 1}$ & $\mathbf{1 . 3}$ & $\mathbf{5 . 9 5}$ \\
\hline $\mathrm{Si}$ & $\mathbf{2 . 3 1}$ & $\mathbf{1 . 5 9}$ & $\mathbf{4 . 5}$ \\
\hline $\mathrm{P}$ & 11.12 & 6.94 & 3.21 \\
\hline $\mathrm{K}$ & 0.43 & 0.21 & 7.47 \\
\hline $\mathrm{Ca}$ & 18.9 & 9.11 & 1.61 \\
\hline
\end{tabular}

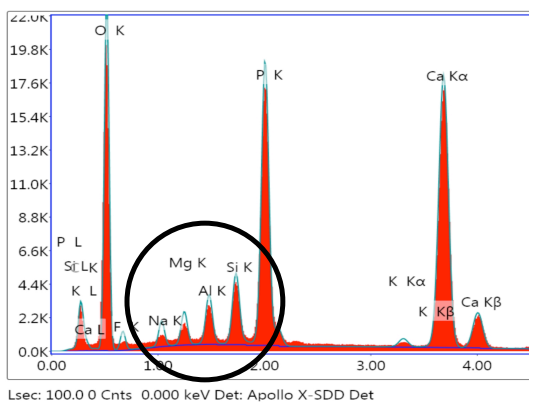

b)

\begin{tabular}{|l|l|l|l|}
\hline Element & Weight & Atomic & Error \% \\
\hline $\mathrm{O}$ & 42.04 & 63.00 & 9.71 \\
\hline $\mathrm{Na}$ & 0.60 & 0.63 & 9.20 \\
\hline $\mathrm{S}$ & 0.06 & 0.04 & 10.32 \\
\hline $\mathbf{P b}$ & $\mathbf{0 . 5 7}$ & $\mathbf{0 . 0 7}$ & $\mathbf{5 . 2 7}$ \\
\hline $\mathbf{F e}$ & $\mathbf{1 . 4 4}$ & $\mathbf{0 . 6 2}$ & $\mathbf{2 . 7 0}$ \\
\hline $\mathrm{P}$ & 15.20 & 11.76 & 2.79 \\
\hline $\mathrm{K}$ & 0.13 & 0.08 & 7.62 \\
\hline $\mathrm{Ca}$ & 39.54 & 23.65 & 1.53 \\
\hline $\mathbf{C u}$ & $\mathbf{0 . 4 2}$ & $\mathbf{0 . 1 6}$ & $\mathbf{6 . 0 1}$ \\
\hline
\end{tabular}

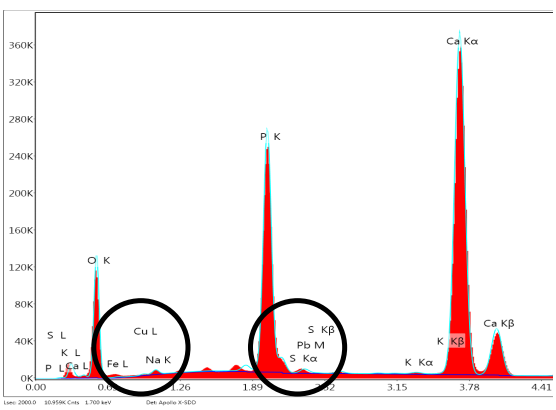

c)

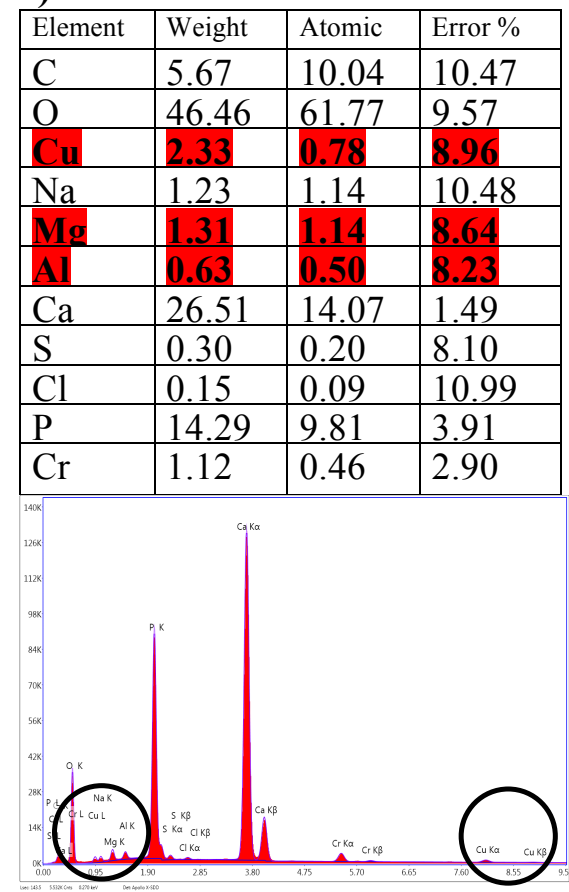

Figure 1. Elemental spectrum of dental calculus of the a) man from Znojmo-Hradiste with magnesium, aluminum and silicate b) soldier from Majetin with iron, lead and copper and c) man from Devin with copper, magnesium and aluminum (chromium was used to coating) 